\title{
A Lockean Theory of Intellectual Property Revisited
}

\author{
ADAM D. MOORE*
}

TABLE OF CONTENTS

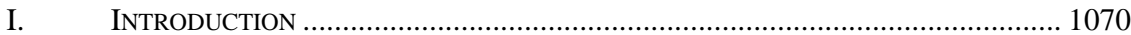

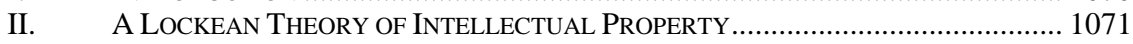

A. Bettering, Worsening, and the Baseline Problem ................................. 1073

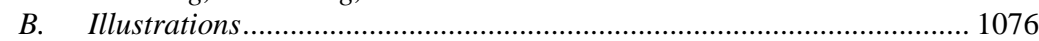

III. PRoBlems FOR THE PROPOSED LOCKEAN ACCOUNT ......................................... 1078

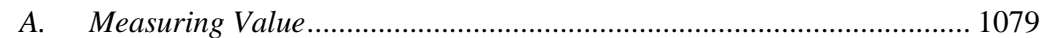

B. Baseline Worries.......................................................................... 1082

C. Final Thoughts About the Baseline Problem ....................................... 1086

D. Mere Use and Possession Rights Objection.......................................... 1088

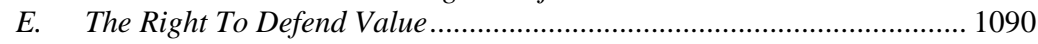

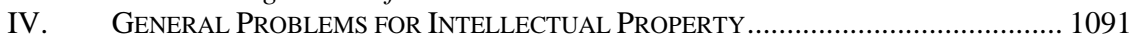

A. The Nonrivalrous Argument: But They Still

Have Their Copy! ....

B. The Free Speech Argument Against

Intellectual Property ............................................................................ 1094

C. The Social Nature of Intellectual Works Argument

Against Intellectual Property.................................................................... 1096

D. Intellectual Property Rights Violate Individual Liberty ......................... 1099

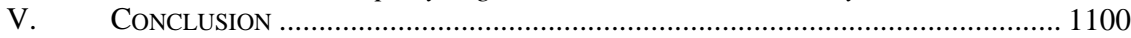

* This Article was presented at the University of San Diego School of Law Institute for Law and Philosophy 2012 Editors' Symposium: The Philosophical Foundations of Intellectual Property conference. I would like to thank Larry Alexander, Steven Smith, Wendy Gordon, Ken Himma, Justin Hughes, David McGowan, Robert Merges, Stephen Munzer, Randy Picker, Ted Sichelman, Shubha Ghosh, Gary Chartier, and the other conference participants for providing helpful comments and suggestions. I would also like to thank the editors of the San Diego Law Review, including Ryan Doyle, Laurel Gilbert, Tripp May, and Nicholaus Norvell, for all of their help. 


\section{INTRODUCTION}

A general form of Locke's famous argument for property rights includes self-ownership, labor, value creation, nonwaste, and leaving "enough and as good" for others. ${ }^{1}$ For Locke, there had to be a process whereby individuals could unilaterally expand self-ownership rights to include objects external to one's body, capacities, and powers. Independent of the consent of one's fellows, individuals could change the moral landscape by creating property rights. Moreover, this expansion of rights allowed individuals the moral space to order their lives as they saw fit, resistant to the demands of society or culture. In this way, Locke offered a view that was deeply individualistic. ${ }^{2}$

The primary, and perhaps sole, function of government according to Locke was to secure and protect the lives, liberties, and property of individuals who consented, explicitly or tacitly, to a specific political union. The question that I will address in this Article, and one that I took up over fifteen years ago, is: should we consider intellectual works to be the proper subjects of Lockean property claims? My answer then and now is "yes," with the acknowledgement that such a view may require substantial revisions to Anglo-American systems of intellectual property. I will argue that intellectual property rights are no different from rights to lives, liberties, and estates - that is, intellectual property rights should not be seen as state-created entities offered as an inducement to bring forth new knowledge.

The upshot of viewing intellectual property rights as state-created monopolies, far too often controlled by the powerful and well-connected, is the seemingly pervasive opinion that systems of intellectual property represent the mafia family on a global scale. In my view, to be justified and to warrant worldwide coercion, systems of intellectual property should be grounded in a Lockean theory of property-a theory that acknowledges and protects the natural rights of authors and inventors.

Part II of this Article will present the main outlines of a Lockean theory of intellectual property. Part III will take up several specific objections that have been leveled against my preferred view. Finally, Part IV will consider several general objections to intellectual property.

1. John Locke, The SECond Treatise of Government § 27, at 17 (Thomas P. Peardon ed., Liberal Arts Press, Inc. 1952) (1690).

2. Some scholars deny this claim about Locke. See, e.g., C.B. MACPHERSON, THE POlitiCAL THEORY OF POSSESSIVE INDIVIDUALISM: HOBBES TO LOCKE 1-4 (1962); JAMES Tully, A Discourse ON PROPERTY: JoHN LOCKE AND HIS ADVERSARIES 174-76 (1980); Lior Zemer, The Making of a New Copyright Lockean, 29 HARV. J.L. \& PuB. POL’y 891, 912-14 (2006). 


\section{A LOCKEAN THEORY OF INTELLECTUAL PROPERTY ${ }^{3}$}

Independent of social progress or utility maximization arguments, John Locke offered what has become known as the "labor theory of acquisition." Locke claimed, "[f]or this labor being the unquestionable property of the laborer, no man but he can have a right to what that is once joined to, at least where there is enough and as good left in common for others." 4 As long as the proviso that "enough and as good [is] left" is satisfied, an acquisition is of prejudice to no one.

Suppose that mixing one's labor with an unowned object creates a prima facie claim against others not to interfere that can be overridden only by a comparable claim. The role of the proviso is to provide one possible set of conditions where the prima facie claim remains undefeated. $^{5}$ Another way of stating this position is that the proviso, in addition to $X$, where $X$ is labor or first occupancy or some other weak claim-generating activity, provides a sufficient condition for original appropriation.

Justification for the view that labor or possession may generate prima facie claims against others could proceed along several lines. First, labor, intellectual effort, and creation are generally voluntary activities that can be unpleasant, exhilarating, and everything in between. ${ }^{6}$ That we voluntarily do these things as sovereign moral agents may be enough to warrant noninterference claims against others.

A second and possibly related justification is based on merit. Sometimes individuals who voluntarily do or fail to do certain things deserve some outcome or other. Thus, students may deserve high honor grades and criminals may deserve punishment. When notions of desert are evoked, claims and obligations are made against others-these nonabsolute claims and obligations are generated by what individuals do or fail to do.

3. A longer version of this Part appears in ADAM D. MoORE, INTELLECTUAL PROPERTY \& INFORMATION CONTROL: PHILOSOPHIC FOUNDATIONS AND CONTEMPORARY Issues 71-194 (2001), and Adam D. Moore, A Lockean Theory of Intellectual Property, 21 HAMLiNE L. REV. 65 (1997).

4. LOCKE, supra note $1, \S 27$, at 17 (emphasis added).

5. This view is summed up nicely by Clark Wolf, Contemporary Property Rights, Lockean Provisos, and the Interests of Future Generations, 105 ETHICS 791, 795 (1995).

6. Ken Himma notes that the creation of intellectual works involves using one of our most precious commodities - bits of our lives. See Kenneth Einar Himma, Justifying Intellectual Property Protection: Why the Interests of Content Creators Usually Win Over Everyone Else's, in InFORMATION TEChNOLOGY AND SOCIAL Justice 47 (Emma Rooksby \& John Weckert eds., 2007). 
Thus, in fairly uncontroversial cases of desert, we are willing to acknowledge that weak claims are generated, and if desert can properly attach to labor or creation, then claims may be generated in these cases as well.

Finally, a justification for the view that labor or possession may generate prima facie claims against others could be grounded in respect for individual autonomy and sovereignty. As sovereign and autonomous agents, especially within the liberal tradition, we are afforded the moral and legal space to order our lives as we see fit. As long as respect for others is maintained, we are each free to set the course and direction of our own lives, to choose among various lifelong goals and projects, and to develop our capacities and talents accordingly. Simple respect for individuals would prohibit wresting from their hands an unowned object that they acquired or produced. I hasten to add that at this point we are trying to justify weak noninterference claims, not full-blown property rights. Other things being equal, when an individual labors to create an intellectual work, weak presumptive claims of noninterference have been generated on grounds of labor, desert, or autonomy.

The underlying rationale of Locke's proviso is that if no one's situation is worsened, then no one can complain about another individual appropriating part of the commons. If no one is harmed by an acquisition and one person is bettered, then the acquisition ought to be permitted. In fact, it is precisely because no one is harmed that it seems unreasonable to object to what is known as a Pareto-superior move. ${ }^{7}$ Thus, the proviso can be understood as a version of a "no harm, no foul" principle.

Before continuing, I will briefly consider the plausibility of a Paretobased proviso as a moral principle. First, to adopt a less-than-weak Pareto principle would permit individuals, in bettering themselves, to worsen others. Such provisos on acquisition are troubling because at worst, they may open the door to predatory activity, and at best, they may give antiproperty theorists the ammunition to combat the weak presumptive claims that labor and possession may generate. Part of the

7. One state of the world, $S_{1}$, is Pareto-superior to another, $S_{2}$, if and only if no one is worse off in $S_{1}$ than in $S_{2}$ and at least one person is better off in $S_{1}$ than in $S_{2}$. $S_{1}$ is strongly Pareto-superior to $S_{2}$ if everyone is better off in $S_{1}$ than in $S_{2}$ and weakly Paretosuperior if at least one person is better off and no one is worse off. State $S_{1}$ is Paretooptimal if no state is Pareto-superior to $S_{1}$, strongly Pareto-optimal if no state is weakly Pareto-superior to it, and weakly Pareto-optimal if no state is strongly Pareto-superior to it. Throughout this Article I will use Pareto superiority to stand for weak Pareto superiority. This construction is adapted from G. A. Cohen, The Pareto Argument for Inequality, 12 SOC. PHIL. \& POL'Y 160 (1995). The Pareto condition is named after Vilfredo Pareto (1848-1923), an Italian economist and sociologist. 
intuitive force of a Pareto-based proviso is that it provides little or no grounds for rational complaint. Moreover, if we can justify intellectual property rights with a more stringent principle, a principle that is harder to satisfy, then we have done something more robust, and perhaps more difficult to attack, when we reach the desired result.

To require individuals, in bettering themselves, to better others is to require them to give free rides. ${ }^{8}$ In the absence of social interaction, what reason can be given for forcing one person, if she is to benefit herself, to benefit others? ${ }^{9}$ If absent social interaction, no benefit is required, then why is such benefit required within society? The crucial distinction that underlies this position is between worsening someone's situation and failing to better it, and I take this intuition to be central to a kind of deep moral individualism. ${ }^{10}$ Moreover, the intuition that grounds a Pareto-based proviso fits well with the view that labor, and possibly the mere possession of unowned objects, creates a prima facie claim to those objects. Individuals are worthy of a deep moral respect, and this grounds a liberty to use and possess unowned objects.

\section{A. Bettering, Worsening, and the Baseline Problem}

Assuming a just initial position and that Pareto-superior moves are legitimate, there are two questions to consider when examining a Paretobased proviso. First, what are the terms of being worsened? This is a question of scale, measurement, or value. An individual could be worsened in terms of subjective preference satisfaction, wealth, happiness, freedoms, opportunities, et cetera. Which of these count in determining

8. I have in mind the Robinson Crusoe case in ROBERT NozICK, ANARCHY, STATE, AND UTOPIA 185 (1974).

9. The distinction between worsening someone's position and failing to better it is a hotly contested moral issue. See DAVID GAUTHIER, Morals BY AgREEMENT 204 (1986); Shelly Kagan, The Limits of Morality (1989); John Harris, The Marxist Conception of Violence, 3 PHIL. \& PuB. AfF. 192 (1974); John Kleinig, Good Samaritanism, 5 PHIL. \& PuB. AFF. 382 (1976); Eric Mack, Bad Samaritanism and the Causation of Harm, 9 PHIL. \& PuB. AfF. 230 (1980); Eric Mack, Causing and Failing To Prevent, 7 Sw. J. PHIL. 83 (1976).

10. This view is summed up nicely by Anthony Fressola:

Yet, what is distinctive about persons is not merely that they are agents, but more, that they are rational planners - that they are capable of engaging in complex projects of long duration, of acting in the present to secure consequences in the relatively distant future, of ordering their diverse actions into programs of activity, and ultimately, into plans of life.

Anthony Fressola, Liberty and Property: Reflections on the Right of Appropriation in the State of Nature, 18 AM. PHIL. Q. 315, 320 (1981). 
moral bettering and worsening? Second, once the terms of being worsened have been resolved, which two situations are we going to compare to determine if someone has been worsened? In any question of harm, we are comparing two states-for example, "now" after an acquisition compared to "then" or before an acquisition. This is known as the baseline problem.

In principle, the Lockean theory of intellectual property being sketched is consistent with a wide range of value theories. So long as the preferred value theory has the resources to determine bettering and worsening with reference to acquisitions, Pareto-superior moves can be made and acquisitions justified on Lockean grounds. For now, assume an Aristotelian eudaemonist account of value exhibited by the following theses is correct ${ }^{11}$ :

1. Human well-being or flourishing is the sole standard of intrinsic value.

2. Human persons are rational project pursuers, and well-being or flourishing is attained through the setting, pursuing, and completion of life goals and projects.

3. The control of physical and intellectual objects is valuable. At a specific time, each individual has a certain set of things she can freely use-and other things she owns-but she also has certain opportunities to use and appropriate things. This complex set of opportunities, along with what she can now freely use or has rights over, constitutes her position materially-this set constitutes her level of material wellbeing.

Although it is certainly the case that there is more to bettering and worsening than an individual's level of material well-being, including opportunity costs, I will not pursue this matter further at present. Needless to say, a full-blown account of value will explicate all the ways in which individuals can be bettered and worsened with reference to acquisition. Moreover, as noted before, it is not crucial to the Lockean model being presented to defend some preferred theory of value against all comers. Whatever value theory that is ultimately correct, if it has the

11. For similar views, see ARistotle, Nicomachean Ethics (G.P. Goold ed., H. Rackham trans., Harvard Univ. Press rev. ed. 1934) (c. 384 B.C.E.); PhILIPPA FoOt, NATURAL GOODNESS (2001); IMMANUEL KANT, FUNDAMENTAL PRINCIPLES OF THE METAPHYSICS OF Morals (Thomas K. Abbott trans., Liberal Arts Press, Inc. 1949) (1785); RalPH BaRTON Perry, General Theory of Value: Its MEANing and Basic Principles Construed in TERMS OF INTEREST (1926); JOHN RAWls, A THEORY OF Justice 424-32 (1971); and HenRy SidgWiCK, The MeTHODS OF Ethics § 4, at 6-11 (7th ed. 1907). 
ability to determine bettering and worsening with reference to acquisitions, then Pareto-superior moves can be made and acquisitions justified on Lockean grounds.

Lockeans, as well as others who seek to ground rights to property in the proviso, generally set the baseline of comparison as the state of nature. $^{12}$ The commons, or the state of nature, is characterized as that state where the moral landscape has yet to be changed by formal property relations. ${ }^{13}$ For now, assume a state of nature situation where no injustice has occurred and where there are no property relations in terms of use, possession, or rights. All anyone has in this initial state are opportunities to increase his material standing. Suppose Fred creates an intellectual work-perhaps a new gathering technique-and does not worsen his fellows; alas, all they had were contingent opportunities, and Fred's creation and exclusion adequately benefits them in other ways. After the acquisition, Fred's level of material well-being has changed. Now he has a possession that he holds legitimately, along with all of his previous opportunities. Along comes Ginger, who creates her own intellectual work and considers whether her exclusion of it will worsen Fred. But what two situations should Ginger compare? Should the effects of Ginger's acquisition be compared to Fred's initial state, where he had not yet legitimately acquired anything, or to his situation immediately before Ginger's taking? If bettering and worsening are to be cashed out in terms of an individual's level of well-being with opportunity costs, and this measure changes over time, then the baseline of comparison must also change. In the current case, we compare Fred's level of material well-being when Ginger possesses and excludes an intellectual work to his level of well-being immediately before Ginger's acquisition.

A slightly different way to put this Lockean argument for intellectual property rights is:

12. Note a common misrepresentation of Locke's view is that in advancing his proviso on acquisition - those who acquire must leave "enough and as good"-he is talking about physical objects or things. But this sets up a straw man and ignores Locke's numerous examples of justified appropriation. For example, taking a good long drink from a river does remove some "stuff" from common use, but it also does not fail to leave enough and as good. Locke is advancing a complex view about value and fungibility. If I put a fence around an apple tree in a forest of other fruit-bearing trees, I have left enough and as good-my acquisition may have left you, in terms of value, unaffected.

13. See NozICK, supra note 8, at 172-82; Jeffery M. Gaba, John Locke and the Meaning of the Takings Clause, 72 Mo. L. REV. 525, 533-36 (2007). 
Step One: The Generation of Prima Facie Claims to Control. Suppose Ginger creates a new intellectual work-creation, effort, et cetera-yielding her prima facie claims to control, similar to student desert for a grade.

Step Two: Locke's Proviso. If the acquisition of an intellectual object makes no one else worse off in terms of level of wellbeing compared to how he or she was immediately before the acquisition, then the taking is permitted.

Step Three: From Prima Facie Claims to Property Rights. When are prima facie claims to control an intellectual work undefeated? Answer: When the proviso is satisfied. Alas, no one else has been worsened-who could complain?

Conclusion: So long as no harm is done, the proviso is satisfied-the prima facie claims that labor and effort may generate turn into property claims.

If correct, this account justifies moral claims to control intellectual property like genetic enhancement techniques, movies, novels, or information. When an individual creates an intellectual work and fixes it in some fashion, then labor and possession create a prima facie claim to the work. Moreover, if the proviso is satisfied, the prima facie claim remains undefeated and moral claims or rights are generated.

\section{B. Illustrations}

Consider the simplest of cases. After weeks of effort and numerous failures, suppose I come up with an excellent recipe for spicy Chinese noodles-a recipe that I keep in my mind and do not write down. Would anyone argue that I do not have at least some minimal moral claim to control the recipe? Suppose that you sample some of my noodles and desire to purchase the recipe. Is there anything morally suspicious with an agreement between us that grants you a limited right to use my recipe provided that you do not disclose the process? Alas, you did not have to agree to my terms, and no matter how tasty the noodles, you could eat something else.

Here at the micro level, we get the genesis of moral claims to intellectual works independent of social progress or incentive-based arguments. Also, it should be highlighted that, like other rights and moral claims, effective enforcement or protection may be a matter left to governments-protection of rights is one thing, while the existence of rights is another. 
Consider a second case. Suppose Fred, in a fit of culinary brilliance, scribbles down a new recipe for spicy Chinese noodles and then forgets the essential ingredients. Ginger, who loves spicy Chinese food, sees Fred's note and snatches it away from him. Under my view of Locke's theory, the proviso has been satisfied by Fred's action, and Ginger has violated Fred's right to control the collection of ideas that compose the recipe. We may ask, "What legitimate reason could Ginger have for taking Fred's recipe rather than creating her own?” If Ginger has no comparable claim, then Fred's prima facie claim remains undefeated.

We can complicate this case by imagining that Fred has perfect memory, and so Ginger's theft does not leave Fred deprived of that which he created. It could be argued that what is wrong with the first version of this case is that Fred lost something that he created and may not be able to recreate-Ginger betters herself, without justification, at the expense of Fred. In the second version of the case, Fred has not lost and Ginger has gained, and so there is apparently nothing wrong with her actions. ${ }^{14} \quad$ But from a moral standpoint, the accuracy of Fred's memory is not relevant to his rights to control the recipe, and so this case poses no threat to the proposed theory. Moreover, the fact that intellectual property rights are hard to protect has no bearing on the existence of the rights themselves. Similarly, that it is almost impossible to prevent a trespasser from walking on your land has no bearing on your property rights. In creating the recipe and not worsening Ginger compared to the baseline, Fred's presumptive claim is undefeated and thus creates a duty of noninterference on others. In both versions of this case, Fred has lost the value of control and the control of the value that he created.

Rather than creating a recipe, suppose Fred writes a computer program and Ginger simultaneously creates a program that is in large part a duplicate of Fred's. To complicate things further, imagine that each will produce and distribute the software with the hopes of capturing the market and that Fred has signed a distribution contract that will enable him to swamp the market and keep Ginger from selling her product. If opportunities to better oneself are included in the account of bettering and worsening, then it could be argued that Fred violates the proviso because in controlling and marketing the software he effectively

14. This case trades on the nonrivalrousness of intellectual works - unlike an apple, we both can benefit from a recipe. The force of nonrivalrous arguments against intellectual property will be considered below. See infra Part IV.A. 
eliminates Ginger's potential profits. The problem this case highlights is that what individuals do with their possessions can affect the opportunities of others in a negative way. If so, then worsening has occurred and no duties of noninterference have been created. In cases of competition, it seems that the proviso may yield the wrong result.

This is just to say that the proviso, as I have interpreted it, is set too high or that it is overly stringent. In some cases where we think that rights to intellectual property should be justified, it turns out, on the theory being presented, that they are not. But surely this is no deep problem for the theory. In the worst light, it has not been shown that the proviso is not sufficient but only that it is overly stringent. And given what is at stake - the means to survive, flourish, and pursue lifelong goals and projects-stringency may be a good thing. Nevertheless, the competition problem represents a type of objection that poses a significant threat to the theory being developed. If opportunities are valuable, then any single act of acquisition may extinguish one or a number of opportunities of one's fellows. Obviously, this need not be the case every time, but if this worsening occurs on a regular basis, then the proposed theory will leave unjustified a large set of acquisitions that we intuitively think should be justified.

Before concluding this brief overview of a Lockean theory of intellectual property, I would like to discuss a strategy for answering the competition problem and related concerns. Continuing with the Fred and Ginger example, it seems plausible to maintain that her complaints are, in a way, illicit. The very opportunities that Ginger has lost because of Fred's business savvy are dependent on the institution of property relations that allows Fred to beat her to market. Moreover, her opportunities include the possibility of others undercutting her potential profits. Contingent opportunities are worth less than their results, and so compensation will be less than it would seem. Compensation for worsening could proceed at two levels. In acquiring some object, Fred himself could better Ginger's position, or the system that they both operate within could provide compensation. This is just to say that it does not matter whether the individual compensates or the system compensates; the agent in question is not worsened.

\section{PROBLEMS FOR THE PROPOSED LOCKEAN ACCOUNT}

While admittedly brief and incomplete, the sketch of the Lockean model of intellectual property offered above indicates the strengths of such an account. I will now turn to several specific objections that have been leveled against this account. My hope is to address these worries and thereby further strengthen and clarify the view. 


\section{A. Measuring Value}

On the account that I have sketched, moral bettering and worsening are to be measured in term of an individual's level of material wellbeing. As I have argued elsewhere, this view is both objective and relational. ${ }^{15}$ An objective account of value holds that value exists independent of human affective states. ${ }^{16}$ As I have stated, "[T]here are reasons for action, and we have to discover them instead of deriving them from our preexisting desires or preferences." ${ }^{\text {"17 }}$ A relationalist about value claims that value is always related to objects-persons, groups, or times, for example. ${ }^{18}$ More specifically, I have argued that moral value is species-relative. ${ }^{19}$ What is valuable for human beings may not extend to nonhuman animals or other living entities, and viceversa.

Subjective accounts of moral value, on the other hand, hold that value is conferred on an otherwise valueless state of the world by our preferences and desires. David Gauthier, a subjectivist about value, writes:

Value does not afford a single uniform measure of preference but a measure relative to each valuer. And although values are ascribed to states of affairs, the ascription is attitudinal, not observational, subjective, not objective. As a measure of preference value is and must be contingent on preferences for its very existence. ${ }^{20}$

I believe that such views fall prey to the problems of arbitrariness, preference manipulation, and value elitism. In any case, a presentation and defense of my preferred account of value is beyond the scope of this Article. Instead, I will focus on some of the common mistakes that scholars have made with how we measure moral bettering and worsening. Consider the following case presented by Jeremy Waldron:

Suppose $\mathrm{Q}$ is dying of a disease for which he knows there is no cure; he resigns himself to his fate and prepares for a stoic death. Then the news comes in: a drug has been developed which will remit the disease. The person who

15. Adam D. Moore, Privacy Rights: Moral and Legal Foundations 34 (2010) [hereinafter Moore, Privacy Rights]; Adam D. Moore, Values, Objectivity, and Relationalism, 38 J. VALUE INQUIRY 75 (2004).

16. MOORE, Privacy Rights, supra note 15 , at 35

17. Id. at 38

18. See id.

19. Id.

20. GAUTHIER, supra note 9, at 25. 
made and tested it, $\mathrm{P}$, did so in his own laboratory with his own hands using his own materials. P makes the drug available to a number of his friends, but excludes Q because he dislikes Q's politics. Clearly Q will suffer something as a result of this. Instead of the stoic death he prepared for, it is likely that the rest of his life will be spent in painful bitterness and anger as he endures the thought that he might have lived and flourished but will not, thanks to P's exercise of this exclusionary right. ${ }^{21}$

Waldron concludes, "Material loss, relative to a given baseline, need not be the only sort of hardship people experience. ... Q is not feigning his distress.... There is real misery that could be relieved, a real bitterness ....,22

Acknowledging that $Q$ may indeed have suffered mental distress, frustrated preferences, and painful bitterness does not establish morally relevant harm. Switching the case slightly drives this point home. Suppose that $Q$ and $P$ are lovers and $P$ ends the relationship so that she can have other partners. $Q$ may suffer mental distress, frustrated preferences, and painful bitterness, but few would maintain that he has been morally worsened by $P$ 's actions.

A critic, perhaps Waldron, may charge that these cases are importantly different. In the first case, we are considering the generation of a property right, while in the second case we are considering what someone may do with her property-in this case, her body. The second case may be an example of self-ownership rights or liberty rights trumping the morally relevant suffering of $Q .{ }^{23}$

Nevertheless, this reply does not solve the worry. Imagine that $P$ was not a self-owner or in possession of liberty rights. However contentious, suppose that $P$ has sold her liberty rights and self-ownership rights to a third party and is seeing $Q$ "on the side," so to speak. When $P$ ends the relationship and causes $Q$ 's heartfelt misery, Waldron would seem to be driven to conclude that $P$ has done something morally blameworthy. A strength of an objective account of moral bettering and worsening is that we can resist this conclusion.

Consider a different case. Suppose Fred and Ginger inhabit a two-person world and neither has established rights to anything, including their own bodies, capacities, and powers. Fred, however, prefers that Ginger not

21. Jeremy Waldron, From Authors to Copiers: Individual Rights and Social Values in Intellectual Property, 68 CHI.-KENT L. REV. 841, 866 (1993) (emphasis omitted).

22. Id. at 867.

23. Suppose $Q$ wakes every morning and obtains peace and serenity by staring at a beautiful fir tree growing in the commons across the valley. After a series of unforeseen accidents, $P$ destroys this tree, causing $Q$ to suffer greatly. Or suppose $P$ chops down the unowned tree and hauls it away to make his house. Sure, we may all agree that $Q$ 's suffering is important and should be met with some compassion, and yet deny that $P$ has done anything morally blameworthy in each of these cases. 
use or control her body, capacities, or powers. In fact, suppose this preference consumes him and generally centers his world. If bettering and worsening are couched in terms of subjective preferences, like painful bitterness or misery, then in controlling her body, capacities, and powers, Ginger worsens Fred's situation. Put aside for a moment the baseline-how Fred would be were Ginger absent. The question at hand is why would Fred's arbitrary, and perhaps silly, preference matter in any way when determining value and bettering or worsening ${ }^{24}$

Sometimes this sort of attack against Lockean accounts of intellectual property comes in terms of frustrated interests. For example, Wendy Gordon presents a case where a preacher harms the interests of his followers by restricting access to an original text:

[S]uppose a preacher instructs his flock to follow precepts that he claims are based on divinely inspired writings, and his audience does in fact follow these rules. Perhaps the precepts contain a ban on birth control, or perhaps a general ban on seeking the help of doctors.... If the doubters in the congregation cannot quote, print, and distribute to like-minded persons the portions of the writings that suggest the preacher's interpretation is not the only or best one, the doubters and those whose interests they serve are harmed. ${ }^{25}$

Perhaps Gordon is using the term interests in an objective way-as a measure of material well-being or species-based flourishing. If so, then I would have no objection. In most cases, however, authors use the term as a subjective notion synonymous with desire, preference, or want. If we want to avoid the view that Fred's mere interests, desires, or preferences in having access to Ginger's body have moral standing, then we need some defensible method for ruling out such preferences. Absent some such method, these accounts of moral bettering and worsening are problematic because they are too broad.

24. The reply usually voiced at this point is that the worry depends on an "odd" or irrational preference. If we rule out such preferences, there is no problem. While initially plausible, I have yet to come across any generally accepted procedure that tells us which preferences count that does not also introduce an "objectifying" element into the account. See MoORE, Privacy Rights, supra note 15, at 34-35.

25. Wendy J. Gordon, A Property Right in Self-Expression: Equality and Individualism in the Natural Law of Intellectual Property, 102 YALE L.J. 1533, 1568 (1993) (emphasis added). 


\section{B. Baseline Worries}

Probably the most common worry that has been leveled against the Lockean view that I have defended focuses on the baseline of comparison. On the account being offered, we determine if worsening has occurred by comparing two states-how someone is before and after an act of creation and exclusion. Consider the Chinese noodles example once again. Prior to my act of creation, the recipe did not exist, so there was no way for others to be worsened because of lack of access. After my creation, others are still without access, so there has been no lessening of flourishing or well-being.

Opponents have rejected this baseline and proposed others. ${ }^{26}$ Consider a different case. What if a perverse inventor creates a geneticenhancement technique that cures cancer, but decides to keep the technique secret or charge excessive prices for access? This case is similar to Waldron's $P$ and $Q$ example mentioned above. ${ }^{27}$ Those individuals who had, before the creation, no chance to survive now have a chance and are worsened because of the perverse inventor's refusal to let others use the machine.

The baseline this case implies cannot be correct. On this view, to determine bettering and worsening, we compare how individuals are before the creation of some value-in this case, the genetic enhancement technique-to how they would be if they possessed or consumed that value. ${ }^{28}$ But we are all worsened in this respect by any value that is held exclusively. I am worsened by your exclusive possession of your car because I would be better off if I exclusively controlled the car-even if I already owned hundreds of cars. If this were the correct comparison, then my exclusive possession of my heart-a value-would worsen others who did not have possession and exclusive title. All individuals, especially those who have faulty hearts, would be better off if they held title to my heart compared to anyone else's holding the title. Moreover, this would be true independent of anyone's choices. Imagine that you voluntarily toss your dinner into a vat of acid and then complain to me that I am worsening you because I, who happen to have two dinners, refuse to give you one. Clearly, this account of the baseline makes the notions of bettering and worsening too broad. Simple failures to benefit

26. See id.; Waldron, supra note 21, at 866.

27. Waldron, supra note 21, at 866.

28. This sort of baseline confusion infects Professor Colin Farrelly's argument that social justice considerations lower the threshold for overriding intellectual property and privacy rights. Colin Farrelly, Genes and Social Justice: A Rawlsian Reply to Moore, 16 BiOETHICS 72, 75 (2002). 
cannot constitute morally relevant worsenings that may in turn justify moral or legal sanctions.

Reconsider Waldron's case where $P$ creates a cure for cancer and excludes $Q$ from the drug. ${ }^{29}$ Rather than focusing on the measure that Waldron selected-painful bitterness - consider the baseline. In Waldron's case we compare how $Q$ is prior to the creation of the cure to how he is after the creation. Before, $Q$ is not doing so well, but after, he is doing even worse. Rather than considering the distribution of value in two states, we compare the distribution of disvalue.

It should be obvious that Waldron's baseline in this case is too broad-determining moral bettering and worsening with this comparison will get it wrong. For example, on this account, when Jones fails to take a punch for Smith, Jones has worsened Smith. Smith compares how he is having been punched by some third party to how he would be if Jones had suffered the punch.

Consider the case where Fred says to Ginger, "I will save your life, but only if you become my house servant." Independent of whether this is a coercive threat or offer, we may ask at least two important questions. First, assuming that Ginger does not indicate agreement with the offer, does Fred's inaction-and Ginger's subsequent death-worsen her? Second, would Ginger's agreement under duress and subsequent failure to comply with Fred's terms constitute a harm to Fred? Assuming that there are no other moral obligations in force, Fred's inaction and Ginger's death would not constitute a morally relevant harm. If they did, then any inaction where some action could prevent a harm would violate this baseline and constitute a morally relevant worsening. I hasten to note that I do not deny the possibility of positive obligations existing among individuals where failure to live up to an obligation would constitute a morally relevant worsening. What I deny is that such positive obligations exist between any two individuals or groups of individuals regardless of history, circumstance, agreement, or prior choices.

Taking up the second question, I would argue that Ginger's agreement under duress and subsequent failure to comply with Fred's terms do not constitute a harm to Fred. Fred's baseline does not include all the benefits he could secure through "forced" contracts any more than Ginger's baseline includes all the benefits she could obtain if others gave

29. See Waldron, supra note 21 , at 866. 
her things. To put the point another way, Ginger has a legitimate complaint against Fred's insistence that she has agreed to and therefore should become his servant.

Moreover, those of us who fail to aid others or prevent harms to others have a legitimate complaint as well. Why should our lives be subject to the demands of others without conditions? Suppose I could easily reach out, take an apple, and eat it-thus providing myself sustenance-but fail to do so. It seems quite implausible to say that in this case, those who fail to act and provide the apple have harmed me.

Shelly Kagan's King and Queen case ${ }^{30}$ provides an interesting challenge to "moment before compared to moment after baselines." Suppose that while eating dinner, the Queen begins to choke and the King rushes to her aid. As he pounds her on the back in an attempt to dislodge the food, he also deliberately stabs her in the leg. While her life is saved, the Queen's leg is severely damaged. ${ }^{31}$ The problem should be obvious. Prior to the King's action, the Queen was going to choke to death, while after his action she is going to live, albeit hobbled. So by simultaneously saving her and stabbing her, the King does not worsen the Queen. Yet there is something wrong about saying that the King bettered, or at least did not worsen, the Queen in this case.

Such examples trade on a difficulty in describing acts. We could describe the action in this case numerous ways: the King saved the Queen's life by pounding her on the back and dislodging the food; the King stabbed the Queen in the leg; the King exhaled, jumped three feet across the room, dropping his napkin, and hit the Queen in the back while imagining how his actions would cause others to worship him as a hero; and so on. I hope it is clear that simply because there is practically an infinite number of ways to describe an action it does not follow that each description is equally good. ${ }^{32}$

Taken by itself, the first action, dislodging the food that the Queen was choking on, would pass the proviso, while the second, stabbing the Queen in the leg, would not. It is not as if these two actions must come

30. See KAGAN, supra note 9 , at 97.

31. Id.

32. Eric D'Arcy and David Lyons both independently develop answers to the problem of act description. In general, their theories distinguish between acts, circumstances, and consequences. The solution that both seem to advocate is that we use moral norms to determine the relevant description of a particular act. Because utilitarians are concerned with the goodness of consequences, we should describe an act in such a way that all the relevant consequences are included. See ERIC D'ARCY, Human ACTS: AN ESSAY IN Their Moral Evaluation 1-61 (1963); DAVID LyOns, Forms AND Limits of UTILITARIANISM 30-61 (1965). 
together - as if a necessary part of the act of saving included the act of stabbing. If it did, then there would be no worsening.

Also, this case, along with many of the others that have been discussed, tends to trade on our moral feelings in an illicit way-there is a moral swamping phenomenon present. Perhaps the moral aversion we have with these cases has more to do with the intentions and sentiments of the agents involved than a rejection of a specific baseline. The King does not have to stab the Queen to save her, and Waldron's $P$ seems like an ass by excluding $Q$ from a cancer cure for political reasons. Take a less emotionally charged example. Friday comes along and he has a choice to do nothing and allow a piano to fall and be destroyed, or he could prevent the piano from being damaged. Beyond this, Friday knows nothing else about the piano-for all he knows, destroying the piano is exactly what the owner wants. Friday does nothing and the piano is destroyed. Crusoe, the owner, confronts Friday and declares that he has lost something of value-Friday's inaction has caused a loss of value for Crusoe. Again, such baselines appear too broad.

A different sort of swamping occurs when we test a baseline with a case that is based upon unjust actions - these cases are morally loaded in a different way, but nonetheless swamp our moral intuitions. Take the case where Friday punches Crusoe in the face several times and is about to make a second round of swings. Crusoe protects himself by striking first. Few would deny that Crusoe has harmed Friday in this case. But it is equally true that few would maintain that this harm constitutes a moral worsening. ${ }^{33}$ An example of swamping is also found in the following case presented by Gordon:

[A]ssume that $A$ takes substances from the common from which, with great ingenuity, she manufactures an enzyme that greatly improves one's health. Because of its salutary properties, a decision is made to include the enzyme in the drinking water. The benefits, however, come at the cost of a particular form of addiction: some people who drink the enzyme become unable to metabolize carbohydrates without continued intake of this elixir. To people so

33. James Wilson's dismissal of what he calls a nonnormative baseline provides a different sort of mistake. Historical baselines, now compared to some point in the past, are rejected en masse because of the case where slave owners would be harmed by legislative changes that outlaw slavery. But this is precisely why theorists who defend such accounts use examples where there are no moral obligations or injustices in place. As discussed, there is a moral-swamping phenomenon present that clouds our judgments. A baseline that concludes that slave owners are morally harmed with emancipation legislation just cannot be correct. See James Wilson, Could There Be a Right To Own Intellectual Property?, 28 LAW \& PHIL. 393, 406 (2009). 
affected, ordinary food becomes valueless for nourishment-it is useless unless eaten along with the enzyme. In such a case, the fact that the common continues to have an ample supply of both food and the elements from which the enzyme can be made is not sufficient to protect the public from harm. The addicted public also needs $A$ 's knowledge of how the enzyme is manufactured, for without it, they will starve in the midst of plenty. If, after the enzyme is put into the water supply, the inventor is given a right to prohibit others from using her manufacturing technique, addicted members of the community are worse off in their ability to use the common than they were before. ${ }^{34}$

My first question when considering this case was, did everyone agree to have the enzyme included in the drinking water? Gordon merely says "a decision [was] made." Suppose not. Suppose this is just an example of a foisted benefit with a huge risk attached. I would agree that if this benefit and risk were foisted, then withdrawing the enzyme after numerous individuals have become addicted and causing their deaths would be a morally relevant harm. But suppose, on the other hand, Jimmy, the risk taker, agreed to ingest the enzyme along with all the associated risks. Now it is not at all clear that our inventor, $A$, has done something wrong when she decides to remove the product from circulation. ${ }^{35}$ Simply put, without the past injustice of the foisted benefit, risk, and addiction, there would be no morally relevant worsening.

\section{Final Thoughts About the Baseline Problem}

As the cases discussed indicate, we need to be cautious when testing a specific baseline. Moreover, providing an argument for a particular baseline-independent of the case-based strategy I have used above-is difficult, although I have attempted such an argument elsewhere. ${ }^{36}$ Nevertheless, there are some general guidelines that fall out of the discussion so far.

First, any baseline that offers a simple comparison of having some value to not having it, or having some disvalue to having more disvalue or no disvalue, is not suitable. All of these baselines fail because they do not take into account the free choices and actions of individuals. Again, suppose I could easily reach out, take an apple, and eat it—thus providing myself sustenance-but fail to do so. It seems quite implausible to say that in this case those who fail to act and provide the apple have morally harmed me. If so, when Jones fails to take a punch for Smith or if I fail

34. Gordon, supra note 25, at 1567.

35. This possibility would be a good reason for Jimmy to never agree to becoming addicted in the first place-or a reason to insist on learning how to make the enzyme himself or having a lifetime supply, et cetera.

36. See MOORE, Privacy RIGHTS, supra note 15, at 63-66. 
to provide you dinner after you have destroyed your own, morally relevant worsenings will have occurred. These baselines are too broad.

Another important restriction is that baselines should be tied to the measure or account of value being employed. Suppose pleasure and pain are the measures, and we compare how Smith is now after Linda punches him in the face with his state two weeks ago when he was in a car wreck and in great pain. Because Smith is better off now in terms of pain compared to immediately after the wreck, we would conclude that he has not been worsened by Linda's punch. But this cannot be correct-we have the wrong baseline.

Although I remain skeptical, consider a different measure-suppose some version of preference theory is correct. Because preferences change over time, baselines that do not reflect these changes will not work. Suppose we compare my level of preference satisfaction now to some week when I had massive preference frustration. In such a case, you would be able to frustrate most or all of my current preferences because your actions would not drive my preference levels below what they were during the comparison week. Thus, if the measure changesif it is dynamic rather than static - then the baseline of comparison must also change.

We must also take care to avoid different swamping phenomena or morally loaded situations that predetermine some result we desire. Simultaneously saving and crippling someone or being overly callous with the health or well-being of others are not positions from which we arrive at cool and reflective endorsement of some principle of moral worsening.

Consider, once again, the baseline that I have offered. We determine if moral worsening has occurred by comparing an individual's level of well-being or flourishing after the act in question to how they were immediately before the action. In the case of intellectual property, we are considering the moments before and after an act of creation and exclusion. ${ }^{37}$ It is important to note that we also must take a morally

37. Take the simplest of cases-what I call a face-puncher case. In a morally neutral world with no past injustices, wrongs, or provocations, suppose Ginger punches Fred in the face. We compare Fred's state after the punch to before and conclude that Ginger's action has morally worsened Fred. To be sure, we could complicate this case. Assume that prior to Ginger's punch, Fred was in great pain-so great that a punch from Ginger would have no overall effect. We could also complicate the case by assuming that Fred cannot feel pain, is compensated by Ginger after the fact, or has agreed to being 
neutral stance in considering the appropriateness of this or any baseline. Assuming no past injustice, moral wrongs, or bad choices, and insisting on a defensible measure, we can clear away much of the rubbish that has been offered concerning baselines for determining moral bettering and worsening. ${ }^{38}$

\section{Mere Use and Possession Rights Objection}

A different sort of objection to the view that I have defended centers on the type of rights generated by labor and nonworsening. According to this worry, my Lockean account generates nothing more than use and possession claims for authors and inventors. Use and possession claims fall well short of the bundle of rights associated with full ownership. Full legal ownership includes:

1. The right to possess - that is, to [enjoy] exclusive physical control of the thing owned ....

2. The right to use - that is, to personal enjoyment and use ....

3. The right to manage - that is, to decide how and by whom [the object] shall be used.

4. The right to the income - that is, to [enjoy] the benefits derived from foregoing personal use ....

5. The right to the capital-that is, the power to alienate the thing and to consume, waste, modify, or destroy it.

6. The right to security - that is, immunity from expropriation.

7. The power of transmissibility - that is, the power to devise or bequeath the [object].

8. The absence of term - that is, the indeterminate length of one's ownership rights.

9. The prohibition of harmful use - that is, one's duty to forbear from using the thing [to harm] others.

10. Liability to execution - that is, liability to having the thing taken away for repayment of a debt.

11. Residuary character - that is, the existence of rules governing the reversion of lapsed ownership rights. ${ }^{39}$

punched. Nevertheless, as a first step, we need to get the easy cases correct and then move on to more difficult ones.

38. Perhaps John Rawls's original position may be of some service here. According to Rawls, we pick the principles of justice that will determine the benefits and burdens of social interaction from a situation where individuals are ignorant of their real-life concerns - they are behind a veil of ignorance that ensures an unbiased choice situation. RAWLS, supra note 11, at 12. Rather than picking principles of justice from this position, suppose we were trying to determine the correct baseline and measure for analyzing moral bettering and worsening. Arguably many of the considerations that I note would be confirmed by such an analysis.

39. Lawrence C. Becker, Property Rights: Philosophic Foundations 19 (1977); see also A. M. Honoré, Ownership, in OXFORD ESSAYS IN JURISPRUDENCE: A Collaborative Work 107, 113 (A. G. Guest ed., 1961) (describing these eleven rights as the "leading incidents" of property ownership). 
At best, so the objection goes, the Lockean account under consideration provides a compelling rationale for (1) and (2) — we get nowhere near (3) through (11). ${ }^{40}$

First, it should be noted that the Lockean account under consideration is not intended to establish full legal ownership of intellectual works. By my lights, if exclusive use, possession, and management rights could be justified, that would be good enough.

Second, in a range of cases, this sort of objection might simply be false. On my view, authors and inventors - on the basis of use and possession claims along with a general right to make contracts-may justifiably bargain for the rights codified in (3) through (11). In small communities it may even be possible to contract with all of one's fellows, securing all or some of the bundle of full ownership. In this sort of example, every single member of the community would be directly part of the agreement. Ginger says to her peers, "If you want access to my recipe, then you will have to agree to my right to enjoy income," and they reply, "But such rights cannot be indefinite-we as a community will not be on the hook for defending this agreement indefinitely." In the ensuing give-and-take, an agreement is hammered out. It is important to note that the moral bindingness of such an agreement is crucially dependent on the initial set of entitlement claims generated by labor, desert, and nonworsening. If Ginger, in this case, was not the author of the recipe- -suppose she took it from someone else-it is not at all clear that the resulting contract would be morally or legally binding. ${ }^{41}$

Moving from small communities to larger ones, we can consider a more general form of agreement among authors, inventors, and society. If intellectual works are to be held as anything other than trade secrets, walled off with narrow contracts like nondisclosure agreements or noncompetition arrangements, there must be a way of securing access. Society may purchase access by offering limited rights to authors and inventors. Moreover, if some society does not offer this sort of

40. I would like to thank Wendy Gordon for this objection.

41. Justin Hughes offered the following counterexample to this view. Suppose indigenous person $X$ is in possession of some intellectual work $B$. $X$ is in possession of $B$ via theft or fraud. Along comes $Y$, who obtains an agreement regarding the use of $B$. $Y$ agrees to the terms in question because $X$ either threatens $Y$ with a poison dart-gun or promises to destroy or hide $B$. Although it is true that $Y$ may indeed agree to a set of ownership policies regarding $X$ and $B$, it is not at all clear that this agreement morally or legally binds $Y$. To see this, switch the case to one where $X$ is a mafia thug who is in possession of powerful weapons and stolen intellectual works. 
protection, innovators would likely employ their talents in other areas or simply move to a society where such agreements are recognized. Rather than a contract between some inventor and each member of her community, we imagine a more general agreement among inventors and the larger society where they reside. In either case, the relatively modest claims secured by labor, desert, and nonworsening may be strengthened into full or nearly full property claims.

\section{E. The Right To Defend Value}

While admittedly speculative and independent of agreements among citizens or innovators and society, there is at least one other argument that might establish exclusivity beyond possession and use. Imagine that Smith has spent days working on an artifact that has great value in terms of providing for human well-being. Assuming the proviso is passed-as I have construed it - and the other conditions are satisfied, we may claim that Smith has use and possession rights to the artifact. Smith wanders off and returns to find Jones has taken possession of the artifact. In reply to various warnings, Jones simply claims that all of Smith's efforts to create the artifact in question yield nothing more than mere use and possession claims - claims that vanish once Smith has given up immediate possession.

I would argue that this is incorrect for two reasons. First, Smith has invested part of his life in creating the artifact. By itself, it would seem that such effort should yield stronger moral claims than what is asserted by Jones when he takes possession. There is a moral difference-one has invested part of his life while the other has simply taken possession. Moreover, Smith can justifiably complain in a way that Jones cannot. Had Smith not created or had Smith never given up possession of the artifact, Jones's position would remain unchanged. This is not true when Jones takes possession.

Second, given the investment, it may be reasonable for Smith to defend the value in question from Jones or anyone else. Jones may destroy the artifact or treat it harshly given that he has not invested anything significant in its creation or maintenance. If we assume that bits of our lives - the time we invest - are one of the most valuable of commodities we control, then on grounds of self-defense we may insist that Smith has the right to defend the value that he created. When Jones unjustifiably attacks Smith, most would agree that self-defense would be an option. Smith has the right to defend his body, capacities, and powers from the attack. Certainly, for Smith, his body, capacities, and powers are valuable, and it is appropriate that he defend these values. By extension, Smith would be permitted to defend the artifact that he 
created from Jones, and a step toward exclusivity will have been established. Although it is true that we are far from justifying full legal ownership, which may fall out of the social contract view already discussed, we have nonetheless secured exclusive use and possession claims that hold independent of immediate possession.

\section{General Problems For INTELlectual Property}

Assuming the account offered so far is compelling, there are several general arguments against intellectual property and systems of intellectual property protection to consider. This is important because it could be that intellectual property rights are overridden by competing or weightier moral claims.

\section{A. The Nonrivalrous Argument: But They Still Have Their Copy! $!^{42}$}

A common argument given by scholars who defend "free access" is that making a copy does not deprive anyone of their possessions. Intangible works are nonrivalrous, meaning that they can be used and consumed by many individuals concurrently. Edwin Hettinger argues:

The possession or use of an intellectual object by one person does not preclude others from possessing or using it as well. If someone borrows your lawn mower, you cannot use it, nor can anyone else. But if someone borrows your recipe for guacamole, that in no way precludes you, or anyone else, from using it. This feature is shared by all sorts of intellectual objects .... .

This characteristic of intellectual objects grounds a strong prima facie case against the wisdom of private and exclusive intellectual property rights. Why should one person have the exclusive right to possess and use something that all people could possess and use concurrently?...

... [T] $\left[\right.$ he unauthorized taking of an intellectual object does not feel like theft. ${ }^{43}$

Consider a more formal version of this argument:

42. For an interesting analysis of this argument, see Kenneth Einar Himma, Abundance, Rights, and Interests: Thinking About the Legitimacy of Intellectual Property Rights, in ETHICS of New Information TeChNOLOgY: ProceEdings of THE SiXth International Conference of Computer Ethics: Philosophical EnQuiry (Philip Brey et al. eds., 2005), available at http://papers.ssrn.com/sol3/papers.cfm? abstract_id=727469.

43. Edwin C. Hettinger, Justifying Intellectual Property, in INTELLECTUAL PROPERTY: Moral, Legal, and International Dilemmas 17, 20 (Adam D. Moore ed., 1997) (footnotes omitted). 
P1. If a tangible or intangible work can be used and consumed by many individuals concurrently (nonrivalrous), then access and use should be permitted.

P2. Intellectual works falling under the domains of copyright, patent, and trade secret protection are nonrivalrous.

C3. So it follows that there is an immediate prima facie case against intellectual property rights or for allowing access to intellectual works.

The weak point in this argument is the first premise-especially given that the second premise is generally true. ${ }^{44}$ Consider sensitive personal information. It seems patently false to claim that just because this information can be used and consumed by many individuals concurrently that there is a prima facie moral claim that this be so. Snuff films, obscene pornography, information related to national security, personal financial information, and private thoughts are each nonrivalrous. Nevertheless, this fact does not, by itself, generate prima facie moral claims for maximal access and use.

Hettinger would likely reply that these sorts of examples would violate a "no harm, no foul" rule that underlies this argument. Taking personal information from someone harms them in a way that copying intellectual works does not. This view lies at the heart of the Lockean argument establishing intellectual property rights. But consider a case provided by Don Hubin and Mark Lambeth:

\begin{abstract}
Dr. Demento ... has discovered a drug that will put people into a trance for eight hours and rejuvenate their bodies so that they need no sleep. The fiendish doctor realizes that he has a way to use the bodies of others without making them any worse off than they would be in his absence.... In addition to making his temporary zombies work in his lab at night, he engages in vile and disgusting sex acts with them which he videotapes ... [and] then sells the tapes at great profit in foreign countries. ${ }^{45}$
\end{abstract}

Arguably, Demento's actions are immoral even though, ex hypothesi, no harm has been done to his subjects. Similarly, a Peeping Tom may engage in immoral activity without harming his victims-perhaps there will be no consequences to the victims and they will never know of the peeping.

44. Some kinds of information are rivalrously consumed — for example, stock tips, et cetera.

45. Donald C. Hubin \& Mark B. Lambeth, Providing for Rights, 27 Dialogue 489, 495 (1988). 
More forcefully, however, if Demento's victims have moral claims to control their own bodies, then they will be worsened by his activity-a moral claim or obligation will have been violated and certain risks imposed without consent.

In summary, the claim that access should be allowed and perhaps promoted for goods that are nonrivalrous is without merit. Intangible works of all sorts are nonrivalrous, including sensitive personal information, financial records, and information related to national security. It may even be the case that our bodies could be nonrivalrously used by others. Nevertheless, this feature of most intangible goods and some tangible goods does not obviously justify such use.

A similar anti-intellectual property argument has been offered by Arthur Kuflik. ${ }^{46}$ Kuflik writes:

[W] hen the inventor makes wheels and starts wheeling things around, he does not interfere in the lives of others or limit their liberty in any way that could provide legitimate ground for complaint. But the same could be said of the others: when they make wheels for their own personal use, they are not interfering in his life or limiting his liberty to make and to use wheels. 47

Kuflik uses this case to show that laboring on and creating ideas, and reducing these ideas to practice does not, and cannot, ground monopoly control because of the nonrivalrous nature of ideas. This also shows, according to Kuflik, that inventors have no exclusive minimal moral claims to the ideas they create. ${ }^{48}$

First, note that monopoly control, a feature of patent protection, is not a necessary feature of systems of intellectual property. Second, I would argue that Kuflik moves too fast. Imagine our inventor had shielded his invention behind a cloak of invisibility and protection. We can see that he is doing something productive and his efforts seem to be more fruitful than his old methods. Suppose Arthur approaches the inventor and demands to see what is behind the cloak. The inventor refuses and claims that what is behind the cloak is his property and if Arthur wants to see and use the item or produce his own copy, he will have to agree to terms. What grounds the force of the contract, assuming that Arthur comes to terms, is the prior entitlement of the inventor.

46. Arthur Kuflik, Moral Foundations of Intellectual Property Rights, in OwNING SCIENTIFIC AND TECHNICAL INFORMATION: VALUE AND ETHICAL IsSUES 219, 223 (Vivian Weil \& John W. Snapper eds., 1989).

47. Id.

48. Id. at 223-24. 
The problem with Kuflik's original case is that the inventor seemingly offers his idea to others without strings, so to speak. In fact, by simply using the wheel within sight of his peers, the inventor foists this idea on others - we are not the sort of beings that can see or hear about an idea and then delete it from memory. Moreover, without any prior agreements regarding use after access, one would assume that making and using a wheel would be fine. ${ }^{49}$ As already noted, however, we can view the Lockean model as a bargain between authors and inventors, who may invest great amounts of time and energy in the production of ideas, and society, which reaps the benefits of this innovation. In return for disclosure and, perhaps, fair use, authors and inventors are protected from those who would copy and use intellectual works after being granted access. Without such agreements, those who innovate would likely either engage in some other productive activity or wall off their creations in other ways.

\section{B. The Free Speech Argument Against Intellectual Property}

A prominent and widespread argument against legal protection of intellectual property is that these systems are inconsistent with our commitment to freedom of thought and speech. ${ }^{50}$ For example, consider how the Church of Scientology has used copyright and other legal protections to restrict access to their religious views. ${ }^{51}$ According to this objection, intellectual property rights are troublesome because they limit access to and uses of intellectual works. This sort of restriction impoverishes the commons of thought and discussion. Lawrence Lessig writes:

Gone with the Wind was published in 1936 ... [and] the copyright would have expired at the end of 1992 . But because of ... extensions ... that copyright now extends until 2031....

49. I would not make this claim when considering private information. I have argued at length that just because someone allows access to private information, it does not follow that those whom have been granted access are at liberty to use this information in any way whatsoever.

50. See, e.g., James Boyle, The Public Domain: Enclosing the Commons of THE Mind 15 (2008); LAWRENCE Lessig, FreE Culture: How Big MEdia Uses TeCHNOLOGy AND THE Law To Lock Down Culture AND ConTrol Creativity (2004); John Perry Barlow, The Economy of Ideas: Everything You Know About Intellectual Property Is Wrong, in INTELLECTUAL PROPERTY, supra note 43, at 349; Gordon, supra note 25; Edwin C. Hettinger, Justifying Intellectual Property, 18 PHIL. \& PuB. AfF. 31 (1989); Melville B. Nimmer, Does Copyright Abridge the First Amendment Guarantees of Free Speech and Press?, 17 UCLA L. REV. 1180 (1970); L. Ray Patterson, Free Speech, Copyright, and Fair Use, 40 VAND. L. REV. 1 (1987); Waldron, supra note 21.

51. See Church of Scientology Int'l v. Fishman, No. 94-55443, 1994 U.S. App. LEXIS 23848 (9th Cir. 1994). 


\begin{abstract}
In 2001, Alice Randall tried to publish [a parody of Gone with the Wind] called The Wind Done Gone. . . . The Mitchell estate . . . brought a federal lawsuit to stop its publication. ...

To most people, this is plainly absurd. Gone with the Wind is an extraordinarily important part of American culture; at some point, the story should be free for others to take and criticize in whatever way they want. ${ }^{52}$
\end{abstract}

The problem with this objection to intellectual property should be obvious. By allowing robust control with specific limits-fair use, idea/expression, sunset on rights-we enhance rather than impoverish the commons of thought and discussion. To put the point another way, a system that allows initial restricted access incentivizes authors and inventors to create intellectual works. These works are then published or distributed, and the result is an enhanced commons of thought and discussion. Simply put, we get more to talk about and build upon by adopting a system of intellectual property.

Moreover, consider the contentious, yet established, idea/expression rule of copyright. ${ }^{53}$ Copyright applies only to fixed expressions - not to ideas that may make up a fixed expression. For example, I may read Einstein's original articles on special and general relativity, express his ideas in my own words, and obtain a copyright in my expression. Sure, I may be guilty of plagiarism, but so long as my expressions are not copied from or substantially similar to Einstein's original, I can obtain a copyright. Perhaps a Lockean could justify this legal rule by appealing to the labor and effort that goes into producing a fixed expression. ${ }^{54}$

If correct, the primary thrust of the free speech argument against intellectual property rights misses an important point. Aside from fair use, the idea/expression distinction in copyright provides a way for ideas to have an impact independent of how authors control their intellectual works. Although it is true that a specific expression and substantially similar artifacts may be controlled and restricted, the ideas that make up the work are, in most cases, free for anyone to consider-information

52. LaWrence Lessig, The Future of Ideas: The Fate of the Commons in A CONNECTED WORLD 198-99 (2001).

53. See 17 U.S.C. § 102(b) (2006) ("In no case does copyright protection for an original work of authorship extend to any idea, procedure, process, system, method of operation, concept, principle, or discovery, regardless of the form in which it is described, explained, illustrated, or embodied in such work.”).

54. Justin Hughes first suggested this analysis. See Justin Hughes, The Philosophy of Intellectual Property, 77 GEO. L.J. 287, 296-330 (1988). 
storehouses like libraries, and now the Web, ensure that access is widespread.

Finally, it is not at all clear that free speech is so presumptively weighty that it nearly always trumps other values. Shouting at someone over a bullhorn all day is not something we would countenance as protected free speech. Hate speech, obscene expressions, sexual harassment, and broadcasting private medical information about others are each examples of speech that we are willing to limit for various reasons-perhaps intellectual property rights can be viewed in this light.

\section{The Social Nature of Intellectual Works Argument Against Intellectual Property}

According to the "social nature of intellectual works" argument, intellectual property unjustly benefits authors and inventors by allowing individuals monopoly control over what is a social product. Proponents of this "shared culture" view would have us imagine that allowing intellectual property rights is like giving the person who places the last brick in a "public works" dam exclusive ownership of the dam. ${ }^{55}$

But like the defender of the first cause argument for the existence of God who rides the principle of sufficient causation to a certain point and then conveniently abandons it-every event or object needs a sufficient cause and nothing is self-caused except God-the proponents of the shared culture view are guilty of a similar trick. Shared culture or the social nature of intellectual property view is sufficient for undermining intellectual property rights or robust control of intellectual works, but conveniently not strong enough to undermine student desert for a grade, criminal punishment, or other sorts of moral evaluation.

More specifically, it is doubtful that the notion of "society" employed in this view is clear enough to carry the weight that the argument demands. In some vague sense, we may know what it means to say that Lincoln was a member of American society or that Aristotle's political views were influenced by ancient Greek society. Nevertheless, the notion of society is conceptually imprecise - one that it would be dubious to attach ownership or obligation claims to. Those who would defend this view would have to clarify the notions of society and "social product" before the argument could be fully analyzed.

But suppose for the sake of argument that supporters of this view come up with a concise notion of society and social product. We may

55. This view is widespread, and virtually every attack on intellectual property includes some version of it. See, e.g., BoYLE, supra note 50; LESSIG, supra note 50; Barlow, supra note 50; Kuflik, supra note 46. 
ask further, why think that societies can be owed something or that they can own or deserve something ${ }^{56}$ Surely, it does not follow from the claim that $X$ is a social product that society owns $X$. Likewise, it does not follow merely from the claim that $X$ is produced by Ginger that Ginger owns $X$. It is true that interactions between individuals may produce increased market values or add to the common stock of knowledge. What may be denied is that these by-products of interaction, market value and shared information, are in some sense owned by society or that society is owed for their use. This should not be assumed without argument. It is one thing to claim that information or knowledge is a social product-something built up by thousands of individual contributions-but quite another to claim that this knowledge is owned by society or that individuals who use this information owe society something in return. ${ }^{57}$

Suppose that Fred and Ginger, along with numerous others, interact and benefit me in the following way. Their interaction produces knowledge that is then freely shared and allows me to create some new value, $V$. Upon creation of $V$, Fred and Ginger demand that they are owed something for their part. But what is the argument from thirdparty benefits to demands of compensation for these benefits? Why think that there are "strings" attached to freely shared information? And if such an argument can be made, it would seem that burdens create reverse demands. Suppose that the interaction of Fred and Ginger produces false information that is freely shared. Suppose further that I waste ten years trying to produce some value based, in part, on this false information. Would Fred and Ginger owe me compensation? Would

56. Do notions of ownership, owing, or deserving even make sense when attached to the concept of society? If so, and if different societies can own knowledge, do they not have the problem of original acquisition? See NozICK, supra note 8, at 178 (pointing out that collective property societies still need to justify why locals have property rights while outsiders do not). Seana Valentine Shiffrin's interpretation of Locke's theory of property appears to fall prey to this worry. See Seana Valentine Shiffrin, Lockean Arguments for Private Intellectual Property, in New Essays IN THE LEgAL AND POLITICAL THEORY OF PROPERTY 138 (Stephen R. Munzer ed., 2001).

57. Lysander Spooner argued that one's culture or society plays almost no role in the production of ideas. "Nothing is, by its own essence and nature, more perfectly susceptible of exclusive appropriation, than a thought. It originates in the mind of a single individual. It can leave his mind only in obedience to his will. It dies with him, if he so elect.” LySANDER SPOONER, The Law of Intellectual Property; or An Essay on the Right of Authors and Inventors to a Perpetual Property in Their Ideas, in 3 THE COLLECTED WORKS OF LYSANDER SPOONER 2, 58 (Charles Shively ed., 1971). 
society? The position that "strings" are attached in this case runs parallel to Robert Nozick's benefit "foisting" example. ${ }^{58}$ In Nozick's case, a benefit is foisted on someone, and then payment is demanded. ${ }^{59}$ This seems an accurate account of what is going on in this case as well.

\begin{abstract}
One cannot, whatever one's purposes, just act so as to give people benefits and then demand (or seize) payment. Nor can a group of persons do this. If you may not charge and collect for benefits you bestow without prior agreement, you certainly may not do so for benefits whose bestowal costs you nothing, and most certainly people need not repay you for costless-to-provide benefits which yet others provided them. So the fact that we partially are "social products" in that we benefit from current patterns and forms created by the multitudinous actions of a long string of long-forgotten people, forms which include institutions, ways of doing things, and language, . . . does not create in us a general floating debt which the current society can collect and use as it will. 60
\end{abstract}

Arguably, common knowledge and shared culture are the synergistic effects of individuals freely interacting. If a thousand of us freely give our new and original ideas to all of humankind, it would be illicit for us to demand compensation after the fact from individuals who have used our ideas to create things of value. It would even be more questionable for individuals ten generations later to demand compensation for the ideas that we freely gave. Lysander Spooner puts the point succinctly:

What rights society have, in ideas, which they did not produce, and have never purchased, it would probably be very difficult to define; and equally difficult to explain how society became possessed of those rights. It certainly requires something more than assertion, to prove that by simply coming to a knowledge of certain ideas - the products of individual labor-society acquires any valid title to them, or, consequently, any rights in them. 61

But once again, suppose for the sake of argument the defender of this view can justify societal ownership of general pools of knowledge and information. Nevertheless, it could be argued that we have already paid for the use of this collective wisdom when we pay for education and the like. When a parent pays, through fees or taxation, for a child's education, it would seem that the information-part of society's common pool of knowledge-has been fairly purchased. And this extends through all levels of education, even to individuals who no longer attend school.

Finally, in many contexts where privacy interests are at stake, for example, an appeal to the social nature of intellectual property and information seems unconvincing - assuming that this view can be saved from the points already discussed. The fact that sensitive personal

\footnotetext{
58. See NozicK, supra note 8, at 95.

59. Id.

60. Id.

61. SPOONER, supra note 57, at 103.
} 
information about an individual's medical history is a social product may have little force when it comes to questions of access and control. This is also true of information related to national security and financial information.

\title{
D. Intellectual Property Rights Violate Individual Liberty
}

Libertarians have attacked the notion of intellectual property on the grounds that it violates individual liberty rights. Tom Palmer argues:

\begin{abstract}
Liberty and intellectual property seem to be at odds, for while property in tangible objects limits actions only with respect to particular goods, property in ideal objects restricts an entire range of actions unlimited by place or time, involving legitimately owned property (VCRs, tape recorders, typewriters, the human voice, and more) by all but those privileged to receive monopoly grants from the state. ${ }^{62}$
\end{abstract}

When an individual owns a physical item, her rights exclude others from interfering with her control of it. But intellectual property rights sweep across the entire domain of human action, restricting individual liberty even in the privacy of one's own home. Palmer continues:

\begin{abstract}
My ownership claim over my computer restricts your access to that computer, but it is not a blanket restriction on your liberty to acquire a similar computer, or an abacus, or to count on your fingers or use pencil and paper. In contrast, to claim a property right over a process is to claim a blanket right to control the actions of others. For example, if a property right [to control] the use of the abacus were to be granted to someone, it would mean precisely that others could not make an abacus unless they had the permission of the owner of that right. It would be a restriction on the liberty of everyone who wanted to make an abacus with their own labor out of wood that they legitimately owned. ${ }^{63}$
\end{abstract}

Palmer concludes that intellectual property rights are morally objectionable and that patent and copyrights institutions should be dismantled. ${ }^{64}$

It is interesting to note, however, that Palmer advocates market and contract, rather than legal, solutions for protecting or fencing intellectual works. $^{65}$ But binding contracts related to intellectual works presuppose justified prior entitlements - thus, to replace Anglo-American copyright and patent institutions with a market and contract model presupposes

62. Tom G. Palmer, Are Patents and Copyrights Morally Justified? The Philosophy of Property Rights and Ideal Objects, 13 HARV. J.L. \& PuB. POL'y 817, 830 (1990).

63. Id. at 831.

64. See id. at 861-65.

65. See id. at 855,860 . 
that authors and inventors have justified entitlements to what they fence. And if authors and inventors have justified entitlements to intellectual works - works that they would not produce or bring forth without certain protections in place-a system of copyright, patent, and trade secret may be adopted.

In response to Palmer's view that intellectual property rights are objectionable because they limit individual liberty, I have two main criticisms. First, this worry may be addressed by adopting specific legal rules. For example, current Anglo-American institutions of intellectual property have built-in provisions that limit the rights of authors and inventors. ${ }^{66}$ These limitations, for example "fair use" and "first sale," allow individuals to use a patented or copyrighted work for personal, nonprofit, or educational purposes. ${ }^{67}$ Under current law it is permissible that I make backup copies of my computer games or copy a chapter of a book from the library. Perhaps these kinds of limitations could be built into the bargain between society and those who create intellectual works.

A second criticism of Palmer's view is that rights of all sorts restrict what individuals can do with their bodies and property. Palmer acts as if restricting individual liberty is a special feature of intellectual property rights and not of other rights. But this is clearly false. My right to a car prohibits all of humanity from swinging a bat and damaging my car. Other people's life rights prohibit you from drinking martinis and playing with a nuclear bomb in your basement. Most rights restrict liberty and prohibit what others can do with their property. ${ }^{68}$ Even in the privacy of your own home, you cannot punch me in the face, destroy my property, or engage in risky activities that threaten your neighbors. Thus, if Palmer's argument works against intellectual property rights, it would seem that it works against all rights, including life rights and tangible property rights. If rights are not a license to do whatever one wills, then Palmer's worry vanishes.

\section{CONCLUSION}

It is important to note that Anglo-American systems of intellectual property are not grounded in a natural rights tradition that Locke or

66. See, e.g., 17 U.S.C. § 107 (2006) (fair use); id. § 109(a) (first sale); id. § 304 (limited duration); see also New Era Publ'ns Int'l v. Henry Holt \& Co., 695 F. Supp. 1493, 1499-1525 (S.D.N.Y. 1988) (discussing fair use), aff'd, 873 F.2d 576 (2d Cir. 1989).

67. See 17 U.S.C. $§ 107$

68. See, e.g., U.S. CONST. amend. IV; Wesley Newcomb Hohfeld, Some Fundamental Legal Conceptions as Applied in Judicial Reasoning, 23 YALE L.J. 16, 32-35 (19131914). 
Lockeans may champion. Beginning with the first Patent Act of 1790 and continuing through the adoption of the Berne Convention standards in 1988, the basis given for Anglo-American systems of intellectual property is utilitarian in nature and incentives based. ${ }^{69}$ Thomas Jefferson, a central figure in the formation of American systems of intellectual property, expressly rejected any natural rights foundation for granting control to authors and inventors over their intellectual work. ${ }^{70}$ "The patent monopoly was not designed to secure to the inventor his natural right in his discoveries. Rather, it was a reward, an inducement, to bring forth new knowledge. ${ }^{, 71}$ Society seeks to maximize utility in the form of scientific and cultural progress by granting rights to authors and inventors as an incentive toward such progress. ${ }^{72}$ In general, patents, copyrights, and trade secrets are devices created by statute to prevent the diffusion of information before the author or inventor has recovered profit adequate to induce such investment. This view is echoed by the committee report that accompanied the 1909 Copyright Act:

69. Limited rights are granted to authors and inventors of intellectual property "to promote the Progress of Science and the useful Arts.” U.S. Const. art. I, § 8, cl. 8.

70. Letter from Thomas Jefferson to Isaac McPherson (Aug. 13, 1813), in 8 THE WRITINGS OF THOMAS JEFFERSON 326, 333 (Andrew A. Lipscomb ed., 1904).

71. William H. Francis \& Robert C. Collins, Cases and Materials oN PATENT LAW: INCLUDing TRADE SECRETS-COPYRIGHTS-TRADEMARKS 93 (4th ed. 1995) (quoting Graham v. John Deere Co., 383 U.S. 1, 9 (1966)). Prior to the enactment of the Constitution, a number of states adopted copyright laws that had both a utilitarian component and a natural rights component. See COPYRIGHT EnACTMENTS OF THE United STATES, 1783-1906 (Thorvald Solberg ed., 2nd ed. 1906). A major turning point away from a natural rights framework for American institutions of intellectual property came with the decision in Wheaton v. Peters, 33 U.S. 591, 660-61 (1834). "Unquestionably, the 1834 decision marked an important turning-point, in that it distanced American copyright law from the natural law perspectives which were very much in evidence at the end of the eighteenth century.” Alain Strowel, Droit d'auteur and Copyright: Between History and Nature, in OF AUTHORS AND ORIGINS 235, 244 (Brad Sherman \& Alan Strowel eds., 1994); see also Edward C. Walterscheid, Inherent or Created Rights: Early Views on the Intellectual Property Clause, 19 HAMLINE L. REV. 81, 103 (1995) ("[The Court] chose to interpret the [intellectual property] clause in favor of the granting of an authority to create a future right rather than an authority to protect an existing one.”). Nevertheless, anomalies still pop up. "In 1984 the Supreme Court cited Locke when it held that intangible 'products of an individual's "labor and invention"' can be 'property' subject to the protection of the Takings Clause." Gordon, supra note 25, at 1540 (quoting Ruckelshaus v. Monsanto Co., 467 U.S. 986, 1002-03 (1984)).

72. For a critique of utilitarian incentive-based justifications of intellectual property, see Adam D. Moore, Intellectual Property, Innovation, and Social Progress: The Case Against Incentive Based Arguments, 26 HAMLINE L. REV. 601 (2003). 
In enacting a copyright law Congress must consider . . . two questions: First, how much will the legislation stimulate the producer and so benefit the public; and, second, how much will the monopoly granted be detrimental to the public? The granting of such exclusive rights, under the proper terms and conditions, confers a benefit upon the public that outweighs the evils of the temporary monopoly. ${ }^{73}$

Control is granted to authors and inventors of intellectual property because granting such control provides incentives necessary for social progress.

As noted in the opening, it seems that adherence to an incentivesbased social progress foundation for institutions of intellectual property has given way to a system where economically privileged elites shape our policy. How else could one interpret Eldred v. Ashcroft, which addressed a challenge to a twenty-year extension of copyright protection provided by the Copyright Term Extension Act of 1998 (the Sonny Bono Act). ${ }^{74}$ In Eldred, seventeen prominent economists, including five Nobel laureates, claimed that adding twenty years to copyright protection would have little impact on incentives to innovate. ${ }^{75}$ The Supreme Court ignored the views of these economists and simply affirmed Congress's decision to extend copyright protection. ${ }^{76}$ If we continue down the road of economic privilege, then we risk undermining both the institutions and the very idea of intellectual property. We end up with the view that intellectual property rights and systems of intellectual property protection are state-created entities controlled by the privileged, connected, and economically advantaged. This would explain the current attitudes about copying and piracy.

Locke wrote, "Nobody could think himself injured by the drinking of another man, though he took a good draught, who had a whole river of the same water left him to quench his thirst....,"77 Given allowances for independent creation and that the frontier of intellectual property is practically infinite, the case for Locke's water drinker and the author or inventor are quite alike. Once a defensible measure and baseline are adopted, we are in a position to consider the actual contributions of authors and inventors. In most cases we are bettered by these intellectual

73. H.R. Rep. No. 60-2222, at 7 (1909); see also Sony Corp. of Am. v. Universal City Studios, Inc., 464 U.S. 417, 477 (1984) (Blackmun, J., dissenting) (describing the copyright system as based on a belief that granting authors exclusive rights over their works would incentivize creativity and ultimately benefit the public welfare).

74. $\quad$ Eldred v. Ashcroft, 537 U.S. 186, 193 (2003).

75. See generally Stan J. Liebowitz \& Stephen Margolis, Seventeen Famous Economists Weigh In On Copyright: The Role Of Theory, Empirics, and Network Effects, 18 HaRV. J.L. \& TECH. 435 (2005).

76. Eldred, 537 U.S. at 194

77. LOCKE, supra note $1, \S 33$, at 20. 
efforts. Perhaps less controversially, we are, at least, not worsened by these activities. In any case, by working out the theoretical underpinnings of a Lockean theory of intellectual property, we may provide a defensible moral foundation for systems of copyright, patent, and trade secret protection. Intellectual property is not theft-rather, intellectual property reflects our commitments to innovative activity and to protecting the natural rights of authors and inventors. 
